\title{
Implementasi kebijakan dan program Corporate Social Responsibility (CSR) perusahaan perkebunan kelapa sawit di PT Perkebunan Nusantara V Provinsi Riau
}

\section{Implementation of Corporate Social Responsibility (CSR) policies and program of palm oil plantation companies in PT Perkebunan Nusantara V Riau Province}

\author{
Agung Nur Haq ${ }^{\mathrm{a}}$, Sambas Basuni ${ }^{\mathrm{b}}$, Arzyana Sunkar ${ }^{\mathrm{b}}$ \\ ${ }^{\text {a }}$ Program Studi Ilmu Pengelolaan Sumberdaya Alam dan Lingkungan, Sekolah Pascasarjana, Institut Pertanian Bogor, Kampus IPB \\ Baranangsiang, Bogor, 16143, Indonesia [+62 81293758049] \\ ${ }^{\mathrm{b}}$ Departemen Konservasi Sumberdaya Hutan dan Ekowisata, Fakultas Kehutanan, Institut Pertanian Bogor, Kampus IPB Dramaga, \\ Bogor, 16680, Indonesia [+62 251-8621947]
}

\section{Article Info:}

Received: 11 - 11 - 2020

Accepted: 29 - 12 - 2020

Keywords:

Charity, CSR Implementation, empowerment, IPA method

Corresponding Author: Agung Nur Haq Program Studi Ilmu Pengelolaan

Sumberdaya Alam dan

Lingkungan, Sekolah

Pascasarjana, Institut Pertanian

Bogor;

Tel. +6281293758049

Email:

agungnurhaq.an@gmail.com

\begin{abstract}
Riau Province is the province with the largest palm oil company in Indonesia, so that the implementation of CSR policies is mostly carried out by palm oil companies in Riau Province. This study aims to measure the performance of the implementation of CSR policies and programs of oil palm plantation companies. This research was carried out at a state-owned company (PTPN V) by taking four examples of garden units based on purposive sampling which were seen from the differences in the location of community life, 3 garden units were in Kampar Regency, and one garden unit in Rokan Hilir Regency. Data analysis was performed using the IPA method which compared the perceptions of the company and the community. The components of the questionnaire compilation for assessing perceptions consisted of the elaboration of statements taken from Government Regulation No. 47/2012 regarding the implementation of CSR and several literature books that explained the implementation of CSR well. The results of this study indicate that the performance of CSR policy implementation that has been implemented by PT Perkebunan Nusantara V is very good in terms of policy content and support, but it needs improvements in the aspects of transparency, CSR programs and results. Transparency and wider information disclosure are important points for affordability towards the target of providing better CSR for the future.
\end{abstract}

How to cite (CSE Style $8^{\text {th }}$ Edition):

Haq AN, Basuni S, Sunkar A. 2020. Implementasi kebijakan dan program Corporate Social Responsibility (CSR) perusahaan perkebunan kelapa sawit di PT Perkebunan Nusantara V Provinsi Riau. JPSL 10(4): $715-724$. http://dx.doi.org/10.29244/jpsl.10.4.715-724.

\section{PENDAHULUAN}

Indonesia adalah produsen minyak kelapa sawit terbesar di dunia, dan minyak kelapa sawit adalah komoditas ekspor terpenting yang menyumbangkan sekitar $10 \%$ dari total pendapatan ekspor. Pada tahun 2018, produksi minyak sawit Indonesia adalah sekitar 38 juta ton dan total luas perkebunan kelapa sawit adalah lebih dari 14 juta hektar (Dirjen Perkebunan Kementan RI, 2019). Kelapa sawit telah berkontribusi terhadap pertumbuhan ekonomi lokal di desa-desa dengan memperkerjakan petani, diantaranya lebih dari lima juta 
petani bekerja di perkebunan di Indonesia, dan 16 hingga 20 juta lainnya terlibat dalam industri pengolahan (Nurfatriani et al., 2018). Badan Pusat Statistik 2017 mencatat, Indonesia secara keseluruhan memiliki kurang lebih 5 juta hektar kebun kelapa sawit badan usaha milik swasta dan 700 ribu hektar Badan Usaha Milik Negara (BUMN). Provinsi Riau merupakan provinsi yang memiliki areal perkebunan kelapa sawit yang paling luas di Indonesia, yaitu seluas 2260941 ha, terdiri atas 569818 ha milik swasta, 59792 ha milik negara yang dikelola PTPN V dan 1383341 perkebunan rakyat. Hal ini menunjukkan bahwa perkebunan kelapa sawit, khususnya di Provinsi Riau sangat besar (BPS, 2017).

Ekspansi kelapa sawit di Indonesia dianggap kontroversial, dan dituduh sebagai penyebab utama kerusakan hutan, kebakaran hutan, hilangnya keanekaragaman hayati, dan konflik sosial (Dayne, 2008). Banyak orang khawatir dengan dampak negatif sosial dan lingkungan, termasuk konflik sosial terkait penguasaan lahan, manfaat terbatas bagi pemilik tanah, dan deforestasi (Rist et al., 2010). Sawit Watch, salah satu LSM Indonesia yang memantau perkebunan skala besar, telah mencatat 632 kasus konflik antara masyarakat lokal dan perusahaan kelapa sawit sejak 2006 (IRIN, 2010). Kemudian tumbuh kesadaran dalam masyarakat sipil tentang pentingnya tanggung jawab sosial perusahaan (CSR), lingkungan dan sosial manajemen, dan sistem keberlanjutan (Achda, 2006).

Penerapan CSR di Indonesia, diatur dalam UU No. 40 tahun 2007 tentang perseroan terbatas, khususnya pasal 74, yang menegaskan bahwa kegiatan CSR diwajibkan pada suatu kegiatan usaha di bidang atau yang berkaitan dengan sumber daya alam. Salah satu kegiatan usaha yang berkaitan dengan sumber daya alam adalah perkebunan kelapa sawit. Kebijakan CSR pasal 74 UU No. 40 tahun 2007 selanjutnya diperjelas dalam PP No. 47 tahun 2012, khususnya pasal 3 ayat 2, pasal 4 ayat 2, pasal 5 ayat 1, dan penjelasan pasal 5 ayat 1 . Pelaksanaan CSR dilakukan di seluruh sektor perusahaan baik milik swasta maupun milik Negara. PKBL adalah program kemitraan dan bina lingkungan, dimana PKBL merupakan istilah CSR untuk BUMN di seluruh Indonesia (Kartini, 2013). Dasar hukum PKBL adalah peraturan Menteri BUMN No.4 Tahun 2007, bahwa setiap BUMN wajib membentuk unit kerja khusus yang menangani langsung masalah pembinaan dan pemberdayaan masyarakat dimana besaran alokasi PKBL tersebut bernilai $2 \%$ dari laba bersih. Belum banyak data terkait bagaimana implementasi CSR dilaksanakan oleh perkebunan sawit negara yang dirasakan oleh masyarakat sekitar, membuat hal ini menarik untuk dibahas untuk dapat mengukur efektivitas dan kinerja implementasi kebijakan dan program CSR perusahaan perkebunan kelapa sawit negara terutama di Provinsi Riau.

\section{METODE}

\section{Lokasi dan Waktu Penelitian}

Penelitian ini dilaksanakan selama 2 bulan (Juli sampai dengan Agustus 2019) pada 4 kebun perusahaan PT Perkebunan Nusantara V di Provinsi Riau.

\section{Metode Pengumpulan Data}

Perusahan yang menjadi contoh penelitian adalah satu perusahaan BUMN (PTPN V). Sementara itu, desa yang dipilih adalah desa-desa dimana program CSR PTPN V dilaksanakan dan sejauh mungkin mewakili ragam program CSR yang dilaksanakan oleh perusahaan. Ragam program dibedakan menjadi program yang langsung diberikan kepada perorangan dan program yang ditujukan untuk kepentingan masyarakat umum, baik yang bersifat derma (charity) maupun dalam bentuk pelatihan.

Responden tersebar pada 4 lokasi kebun PTPN V. Responden yang dipilih dalam penelitian ini adalah mereka yang terlibat dalam program CSR ataupun yang merasakan manfaat dari adanya program CSR perusahaan. Jumlah responden dalam penelitian ini adalah 60 responden masyarakat yang terdiri dari pendamping dan sasaran dalam pelaksanaan CSR, sedangkan pada perusahaan terdiri dari 9 orang yang terdiri dari karyawan pimpinan dan karyawan pelaksana yang dipilih dengan teknik convenience sampling. 
Wawancara dilakukan dengan 2 (dua) pendekatan yaitu wawancara terstruktur dan semi terstruktur. Wawancara terstruktur dilakukan dengan menggunakaan kuesioner, berisi daftar pertanyaan dengan jawabanjawaban yang telah disediakan berupa skor untuk dipilih. Data yang diambil berupa skor persepsi yang berkisar antara 1-5 atas pernyataan dalam kuesioner. Substansi wawancara terdiri atas 4 aspek yaitu isi kebijakan (termasuk program CSR perusahaan), informasi/transparansi kebijakan, dukungan kebijakan, dan hasil/outcome kebijakan.

\section{Metode Analisis Data}

Menurut Carrafio dan Rocco (2007), skala Likert dapat menghasilkan skala pengukuran interval. Skala Likert mempunyai empat atau lebih butir-butir pertanyaan atau pernyataan yang dikombinasikan sehingga membentuk sebuah skor/nilai yang merepresentasikan sifat individu, misalkan pengetahuan, sikap, dan perilaku. Dalam proses analisis data, komposit skor, biasanya jumlah atau rataan, dari semua butir pertanyaan atau pernyataan dapat digunakan (Budiaji, 2013). Tingkatan nilai pada skala interval 1-5 yang digunakan berdasarkan perhitungan statistik adalah sebagai berikut :

Dimana,

$$
\text { Interval }=\frac{\text { skor max }- \text { skor } \min }{\sum \text { kelas }} \approx \frac{(5-1)}{5}=0.8
$$

Skor max $=5$

Skor $\min =1$

$\Sigma$ range $=5$

Analisis persepsi aktor perusahaan dan masyarakat terhadap aspek isi, transparansi, dan dukungan atas kebijakan CSR dilakukan untuk menggambarkan kinerja implementasi kebijakan CSR. Analisis kinerja dilakukan dengan menggunakan metode Important Performance Analisys (IPA) yang dimodifikasi (Xue dan Fang, 2018), dimana sumbu Y menjadi unsur supply yaitu persepsi perusahaan yang melakukan program CSR dan sumbu $\mathrm{X}$ menjadi unsur demand yaitu persepsi masyarakat yang menjadi sasaran dalam pelaksanaan program CSR perusahaan (Gambar 1).

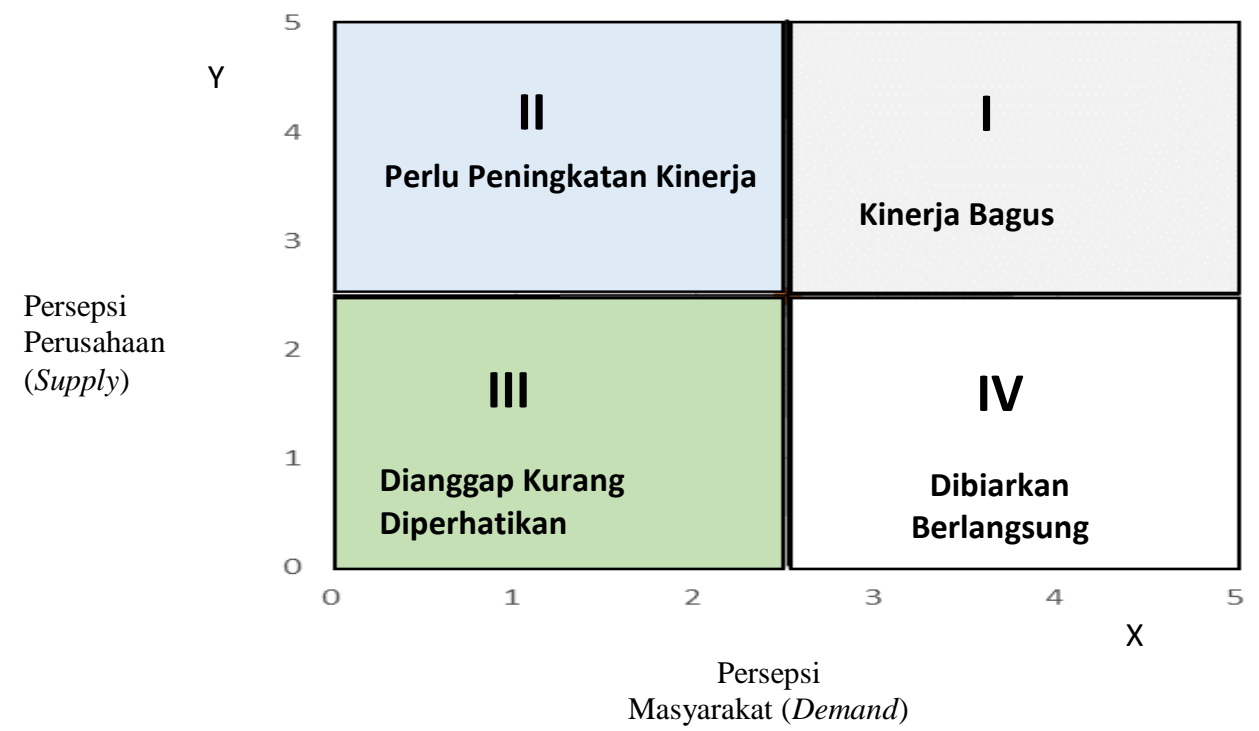

Gambar 1 Diagram IPA kinerja implemnetasi kebijakan CSR PTPN V 
Analisis dibagi dalam 4 kuadran dengan melihat kedua sisi persepsi perusahaan dan masyarakat. Kuadran I menunjukkan persepsi perusahaan dan masyarakat terhadap implementasi kebijakan CSR tinggi, artinya implementasi CSR bagus, sehingga kebijakan dan program CSR layak untuk dilanjutkan. Kuadran II menunjukkan persepsi perusahaan tinggi dan persepsi masyarakat pada rendah, artinya kebijakan dan implementasi CSR perlu ditingkatkan, sehingga menjadi kunci perbaikan kebijakan dan program CSR. Kuadran III menunjukkan persepsi perusahaan dan masyarakat rendah, artinya aspek atau indikator kebijakan dan implementasi CSR kuadran ini dianggap tidak penting sehingga tidak menjadi perhatian perusahaan dan masyarakat, sehingga perlu evaluasi untuk kebijakan dan implementasi CSR selanjutnya. Kuadran IV menunjukkan persepsi perusahaan berada pada tingkat rendah dan masyarakat pada tingkat tinggi, yang artinya kebijakan dan implementasi CSR yang sedikit dilakukan perusahaan dianggap baik oleh masyarakat, sehingga kebijakan dan implementasi CSR pada kuadran ini dapat dibiarkan tetap berlangsung.

\section{HASIL DAN PEMBAHASAN}

\section{Persepsi Perusahaan dan Masyarakat Terhadap Aspek Implementasi Kebijakan dan Program CSR}

Hasil dari keseluruhan aspek (Gambar 2) menunjukkan bahwa kelima aspek implementasi kebijakan CSR yang diteliti tersebar ke dalam 3 kuadran yaitu kuadran 1, 2, dan 3. Aspek isi kebijakan dan dukungan berada pada kuadran 1, yang artinya kinerja implementasi dari aspek tersebut perlu dipertahankan. Aspek transparansi berada pada garis batas antara kuadran 1 dan 2, artinya aspek transparansi perlu menjadi perhatian utama untuk dilakukan pengoptimalan agar dapat menggeser posisinya ke kuadran 1. Aspek program CSR dan hasil berada pada kuadran 3, artinya baik perusahaan maupun masyarakat tidak puas dengan program CSR berjalan. Aspek ini perlu menjadi perhatian lebih karena aspek program CSR dan hasil menjadi komponen penting dalam implementasi kebijakan CSR, sehingga perlu dijadikan prioritas tinggi perusahaan. Hasil penelitian Arifandy et al. (2018) yang dilakukan pada perusahaan yang sama menunjukkan program CSR memiliki korelasi yang signifikan terhadap persepsi masyarakat. Untuk menjawab pertanyaan kenapa aspek tertentu berada di kuadran tertentu, di bawah ini akan dianalisis persepsi masyarakat dan perusahan terhadap masing-masning aspek.

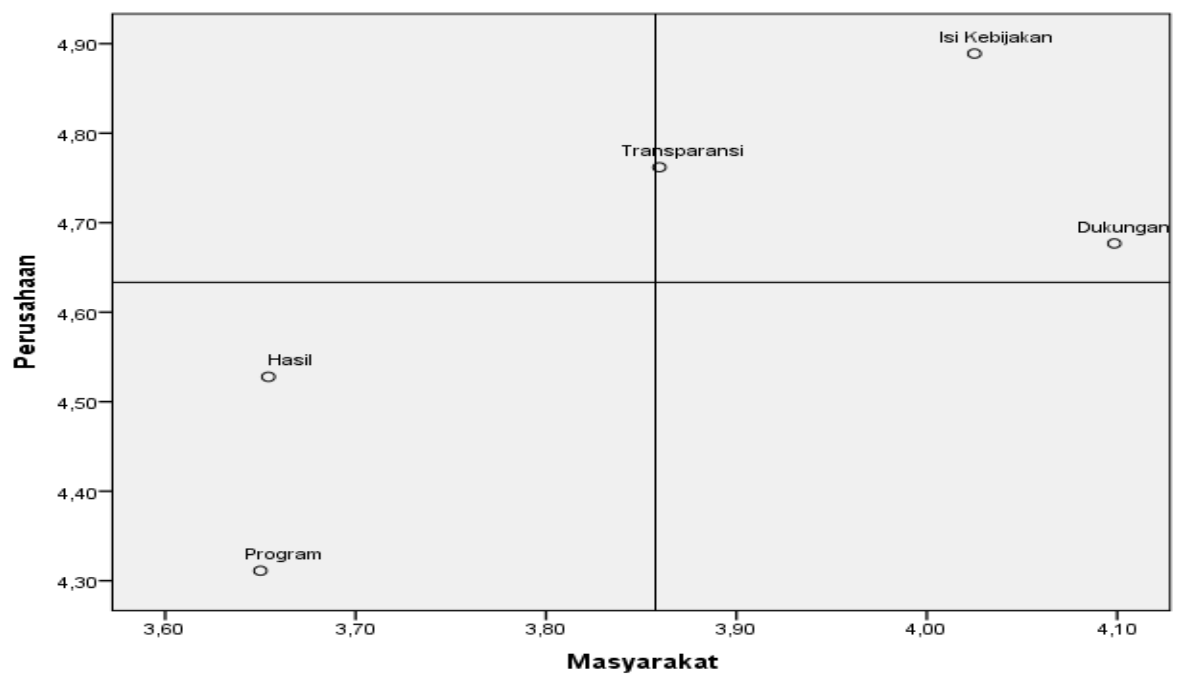

Gambar 2 Diagram IPA aspek keseluruhan

\section{Persepsi Terhadap Aspek Isi Kebijakan}

Data dalam Tabel 1 menunjukkan bahwa persepsi perusahaan maupun masyarakat tergolong sangat puas. Jika digambar dalam diagram IPA, kedua indikator tersebut berada pada kuadran 1. Artinya, kinerja implementasi isi kebijakan berupa ketentuan pasal 4 ayat 2 yang berbunyi: "rencana kerja tahunan PTPN V memuat rencana kegiatan dan anggaran yang dibutuhkan untuk pelaksanaan CSR" dan "Pesan yang tertuang 
dalam pasal 5 ayat 1 PP No. 47 tahun 2012 yang berbunyi "perseroan yang menjalankan kegiatan usaha perkebunan kelapa sawit dalam menyusun dan menetapkan rencana kegiatan dan anggaran harus memerhatikan kepatutan dan kewajaran" perlu dipertahankan. Hasil ini didukung dengan survei yang dilakukan Sugino et al. (2015) pada perusahaan yang menjadi member Gabungan Perusahaan Kelapa Sawit Indonesia (GAPKI), sebanyak 366 perusahaan sudah mengimplementasikan CSR sesuai dengan Undangundang nomor 40 tahun 2007 dari 569 anggota GAPKI dimana terdapat 1151 perusahaan kelapa sawit berskala besar di Indonesia.

Tabel 1 Nilai persepsi terhadap aspek isi kebijakan

\begin{tabular}{ccc}
\hline \multirow{2}{*}{ Indikator } & \multicolumn{2}{c}{ Nilai Persepsi } \\
\cline { 2 - 3 } & Perusahaan & Masyarakat \\
\hline Indikator 1 & 4.89 & 4.08 \\
Indikator 2 & 4.89 & 3.97 \\
\hline
\end{tabular}

\section{Persepsi Terhadap Aspek Transparansi}

Indikator 1 masuk dalam kuadran 2, artinya kinerja implementasi transparansi berupa "Rencana dan pelaksanaan program CSR PTPN V selalu diinformasikan kepada masyarakat Desa Y" menjadi prioritas utama untuk ditingkatkan. Hasil ini sesuai dengan hasil wawancara langsung di lapangan yang kebanyakan menyatakan kurangnya informasi tentang CSR yang mereka terima dari perusahaan. Penelitian yang dilakukan Apriani dan Muhammad (2018) pada perusahaan kelapa sawit di Kabupaten Kutai Timur juga melihat komunikasi menjadi masalah yang perlu diperhatikan, baik komunikasi antara perusahaan dan masyarakat terkhususnya bagi pimpinan-pimpinan perusahaan kepada aparatur-aparatur desa untuk dapat menjalin komunikasi yang lebih baik terkait informasi CSR kedepannya.

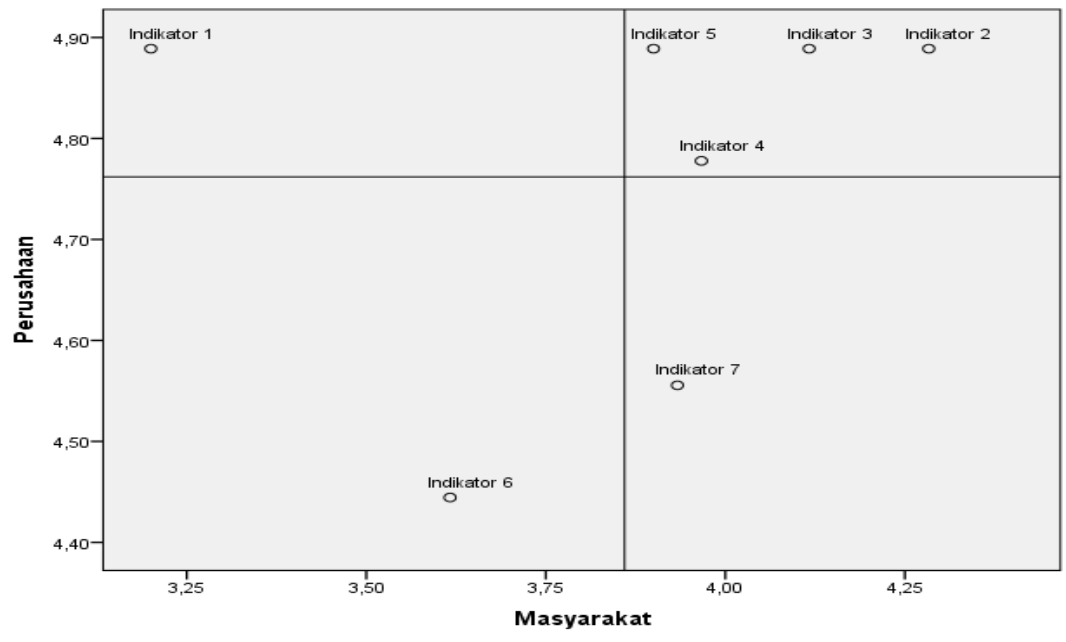

Gambar 3 Diagram IPA aspek transparansi

Indikator 2, 3, 4, dan 5 masuk dalam kuadran 1 (Gambar 3), artinya kinerja implementasi isi kebijakan berupa "Setuju dengan ketentuan peraturan perundang-undangan pasal 3 ayat 2 PP No. 47 tahun 2012 bahwa perusahaan PTPN V melaksanakan CSR di dalam dan di luar lingkungan perusahaan", "Setuju dengan ketentuan peraturan perundang-undangan pasal 5 ayat 1 yang berbunyi: "Perseroan yang menjalankan kegiatan usaha perkebunan kelapa sawit, dalam menyusun dan menetapkan rencana kegiatan dan anggaran CSR harus memerhatikan kepatutan dan kewajaran", "Setuju dengan penjelasan pasal 5 ayat 1 bahwa yang dimaksud dengan kepatutan dan kewajaran" dalam pelaksanaan CSR adalah kebijakan perseroan yang disesuaikan dengan kemampuan dan keuangan perseroan, dan potensi risiko yang mengakibatkan tanggung jawab sosial dan lingkungan yang harus ditanggung oleh perseroan sesuai dengan kegiatan usahanya", dan "PTPN V 
melibatkan masyarakat desa Y secara langsung pada pelaksanaan program CSR" perlu dipertahankan oleh perusahaan. Indikator 6 berada pada kuadran 3, artinya kinerja implementasi transparansi berupa "Perusahaan PTPN V memberikan jaminan bahwa masyarakat desa Y terlibat dalam siklus pelaksanaan program CSR" merupakan indikator yang kurang mendapatkan perhatian dari perusahaan dan masyarakat sehingga kedepan perlu ditingkatkan. Indikator 7 berada pada kuadran 4, artinya kinerja implementasi berupa "Program CSR perusahaan PTPN V memerhatikan kondisi-kondisi lokal dalam pelaksanaannya" sudah memuaskan masyarakat sehingga perusahaan cukup melakukan apa adanya seperti semula.

\section{Persepsi Terhadap Aspek Dukungan}

Indikator 1 dan 11 berada pada kuadran 3, artinya kinerja implementasi aspek dukungan berupa "Perusahaan PTPN V lebih banyak memperkerjakan tenaga lokal" dan "Pelaksanaan program CSR perusahaan PTPN V memiliki kerjasama dengan pihak lain dalam pelaksanaannya" belum menjadi prioritas dalam pelaksanaan CSR perusahaan sehingga kepuasan masyarakat rendah. Indikator 2, 3, 4, 5, 6, 7 dan 8 berada pada kuadran 1 (Gambar 4), artinya kinerja implementasi dukungan berupa "Perusahaan PTPN V tidak menyebabkan kebisingan", "Perusahaan PTPN V tidak menyebabkan air permukaan memburuk", "Perusahaan PTPN V tidak menyebabkan kekurangan air bersih", "Perusahaan PTPN V tidak menyebabkan kebakaran lahan dan hutan", "Perusahaan PTPN V tidak menyebabkan kerusakan jalan umum", "Perusahaan PTPN V tidak menyebabkan kemacetan lalu lintas", dan "Perusahaan PTPN V membuat akses wilayah desa Y menjadi mudah" perlu dipertahankan. Indikator 9 dan 10 masuk dalam kuadran 2, artinya kinerja implementasi dukungan berupa "Pelaksanaan program CSR perusahaan PTPN V dilaksanakan oleh masyarakat dengan pengawasan perusahaan", dan "Program CSR perusahaan PTPN V bersifat berkelanjutan dan memiliki efek positif bagi masyarakat desa Y" menjadi prioritas utama perusahaan untuk ditingkatkan. Hal ini sesuai dengan hasil observasi lapangan dan data dari perusahaan, bahwa perusahaan melakukan program CSR hanya dalam bentuk bantuan langsung. Bentuk bantuan tersebut mengakibatkan kinerja implementasi pada indikator 9 dan 10 menjadi sulit untuk berkembang.

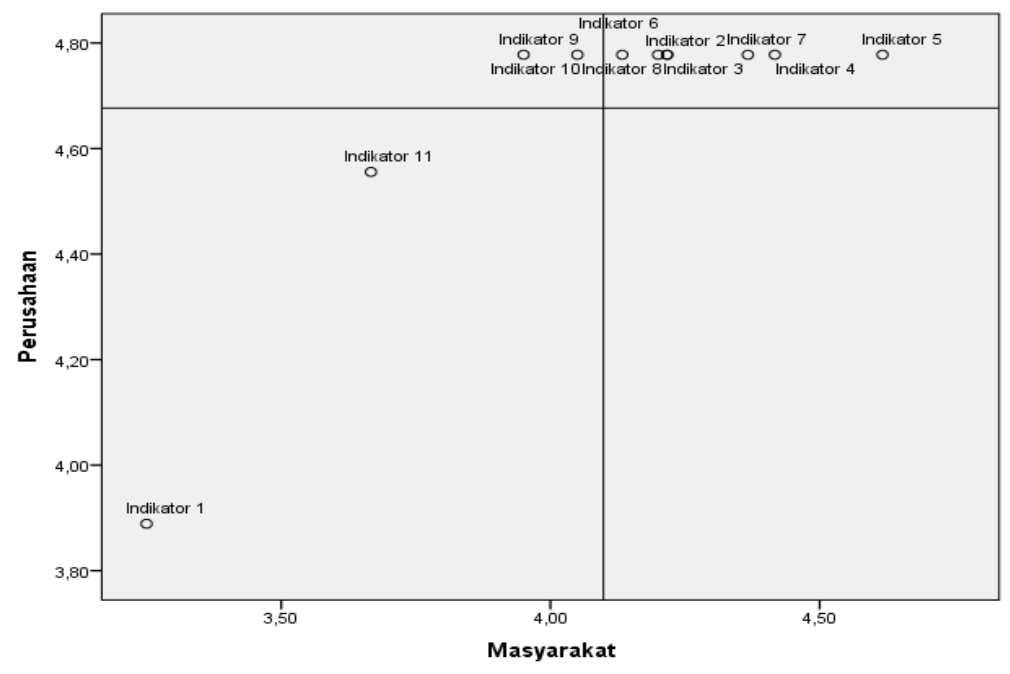

Gambar 4 Diagram IPA aspek dukungan

\section{Persepsi Terhadap Aspek Program CSR}

Indikator 3 berada pada kuadran 1, artinya implementasi aspek program CSR berupa "Bentuk program CSR perusahaan PTPN V lebih diperuntukan untuk bidang sosial di desa Y" perlu dipertahankan dalam implementasi perusahaan. Hal ini sesuai dengan program CSR yang banyak dilakukan oleh perusahaan di bidang pendidikan, kesehatan, sarana peribadahan, maupun bantuan sembako pada bencana alam. Indikator 5 berada pada kuadran 2 (Gambar 5), artinya kinerja implementasi aspek program CSR berupa "Bentuk program 
CSR perusahaan PTPN V lebih diperuntukan untuk bidang lingkungan di desa Y" menjadi prioritas utama perusahaan untuk ditingkatkan. Fokus dari perusahaan terhadap pelaksanaan CSR memang pada bidang sosial dan permohonan proposal yang masuk dari masyarakat hampir seluruhnya berkaitan dengan bidang sosial masyarakat, sehingga wajar jika bidang sosial menjadi indikator yang perlu ditingkatkan oleh perusahaan. Hasil ini sejalan dengan yang ditemukan Dewani et al. (2014) di salah satu perusahaan sawit swasta provinsi sumatera barat, dimana perusahaan memprioritaskan kegiatan program CSR pada bidang sosial sesuai dengan kebutuhan yang dibutuhkan masyarakat sekitar.

Indikator 1, 2, dan 4 berada pada kuadran 3, artinya kinerja implementasi Program CSR berupa "PTPN V mengalokasikan anggaran CSR lebih besar untuk di dalam lingkungan perusahaan dari pada untuk di luar lingkungan perusahaan", "PTPN V mengalokasikan anggaran CSR lebih besar untuk di luar lingkungan perusahaan dari pada untuk di dalam lingkungan perusahaan", dan "Bentuk program CSR perusahaan PTPN V lebih diperuntukan untuk bidang perekonomian di desa Y" belum menjadi fokus perusahaan dalam implementasi CSR. Ketiga indikator yang tergolong dalam kuadran 3 ini merupakan aspek yang penting untuk dapat ditingkatkan menuju kuadran 1. Indikator 1 perlu dilakukan evaluasi lebih lanjut karena juga banyak terdapat masyarakat yang bermukim di dalam areal lingkungan perusahaan yaitu pekerja perusahaan PTPN V terutama yang berstatus karyawaan pelaksana, mereka termasuk perekonomian menengah kebawah. Hasil wawancara dengan masyarakat yang menjadi pekerja yang berada dalam lingkungan perusahaan merasa kurang mendapat perhatian lebih dari perusahaan, diharapkan kedepannya ada perhatian lebih untuk masyarakat di dalam lingkungan perusahaan yaitu para karyawan pelaksana dari perusahaan.

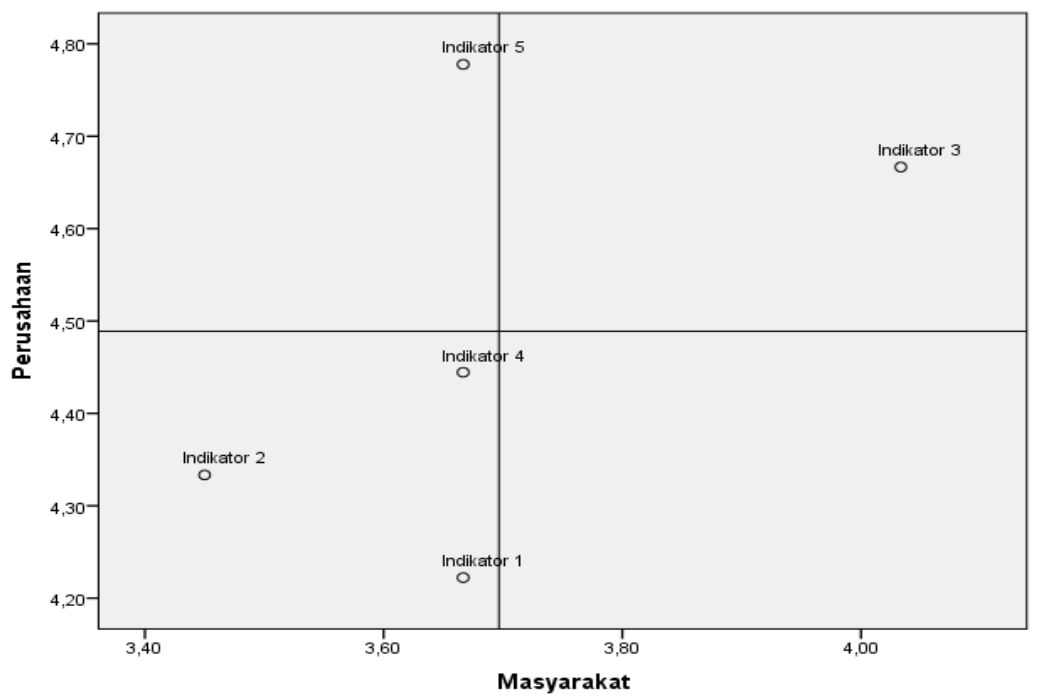

Gambar 5 Diagram IPA aspek program

Indikator 2 perlu menjadi perhatian lebih bagi perusahaan yang sangat perlu ditingkatkan menuju kuadran 1 karena menyangkut persepsi positif masyarakat terhadap perusahaan. Indikator 2 yang berada di kuadran 3 lebih disebabkan oleh sistem pelaksanaan CSR perusahaan PTPN V yang tidak memiliki skala prioritas bagi masyarakat yang berada paling dekat dan terdampak langsung adanya perusahaan. Masyarakat yang berada di dekat perusahaan merasa bahwa kurangnya perhatian perusahaan terkait pelaksanaan program CSR terhadap mereka yang terdampak langsung atau yang areal perusahaan berada di dalam desa mereka. Hasil wawancara menunjukkan bahwa perusahaan menggunakan sistem pengajuan proposal dalam pelaksanaan program CSR mereka. Pengajuan proposal ini bisa dilakukan dalam kisaran skala yang luas, artinya desa yang agak berjauhan dari perusahaan juga dapat melakukan permohonan pengajuan bantuan terhadap perusahaan. Hal ini juga didukung dengan indikator 1 dari aspek transparansi yang menyatakan kurangnya informasi terkait CSR perusahaan, sehingga masyarakat di sekitar perusahaan banyak yang kurang mengetahui dengan adanya sistem dengan pengajuan proposal tersebut. 
Perusahaan menyatakan bahwa CSR dengan sistem proposal karena mengacu pada peraturan dari Menteri BUMN Nomor 2 Tahun 2017 yang mengharuskan pelaksanaan CSR menggunakan proposal sebagai bentuk pertanggungjawaban bagi perusahaan terhadap dana yang akan dianggarkan untuk program CSR. Indikator 4 juga menjadi salah satu poin dalam keragaman pelaksanaan CSR yang dapat dilaksanakan perusahaan. Hasil observasi lapangan menunjukkan bahwa kenapa indikator 4 berada pada kuadran 3 ternyata perusahaan memiliki program tersendiri yang berbeda dengan CSR untuk meningkatkan pertumbuhan ekonomi masyarakat, yaitu perusahaan menyediakan pinjaman lunak bagi masyarakat yang memiliki usaha dengan kriteria yang telah ditentukan oleh perusahaan. Perusahaan membuat program tersebut untuk mendorong semangat masyarakat sekitar untuk melaksanakan usaha. Ada pula pola tanam sawit KKPA (Kredit Kepada Koperasi Primer untuk Anggotanya) yang dijalankan bersama masyarakat sebagai bentuk awal perjanjian perusahaan kepada masyarakat saat membangun perkebunan kelapa sawit di wilayah tersebut.

\section{Persepsi Terhadap Aspek Hasil/Outcome}

Indikator 1, 2, 3, dan 6 berada pada kuadran 1 (Gambar 6), artinya kinerja implementasi aspek hasil berupa "Program CSR perusahaan PTPN V memberikan dampak positif terhadap perkembangan (sesuai bidang CSR yang dipilih perusahaan) terhadap masyarakat desa Y", "Program CSR perusahaan PTPN V memiliki dokumentasi hasil", "Program CSR perusahaan PTPN V dikembangkan oleh masyarakat", dan "Program bantuan/pelatihan perusahaan PTPN V menjadi pengetahuan baru bagi masyarakat" perlu dipertahankan dalam implementasi CSR perusahaan. Indikator 4 dan 5 berada pada kuadran 2, artinya kinerja implementasi aspek hasil berupa "Program CSR perusahaan PTPN V membuat pekerjaan masyarakat menjadi lebih baik", dan "Program CSR perusahaan PTPN V memberikan peningkatan ekonomi pada masyarakat desa Y" menjadi prioritas utama untuk dilakukan pengoptimalan dalam pelaksanaan CSR perusahaan.

Kedua indikator ini tergolong dalam kuadran 2 yang membutuhkan peningkatan kinerja disebabkan oleh pelaksanaan CSR yang dilakukan perusahaan hanya berupa bantuan langsung dengan bantuan uang tunai dan beberapa bersifat kepedulian seperti peminjaman alat berat dan juga sarana transportasi seperti kendaraan bus. Program tersebut menyebabkan tingkat pemberdayaan dirasa oleh masyarakat kurang dilakukan oleh perusahaan seperti pada indikator 4 dan 5. Pasaribu et al. (2020) dalam penelitiannya di Kalimantan Barat menyatakan pentingnya pelaksanaan CSR yang lebih spesifik yaitu community development, dimana program ini lebih menyasar kepada kelompok rentan untuk meningkatkan perekonomian dan Sumber Daya Masyarakat (SDM) serta meningkatkan reduce konflik yang mungkin akan terjadi di masa yang akan datang. PTPN V sendiri sebenarnya sudah melakukan gerakan dalam rangka peningkatan perekonomian masyarakat dengan sistem program kemitraan yang berupa memberikan pinjaman lunak kepada masyarakat sesuai dengan peraturan yang diatur oleh menteri BUMN. Peraturan ini yang membuat PTPN V membedakan antara program yang menyasar untuk peningkatan ekonomi dan program bantuan kepada masyarakat berbeda.

Hal ini sesuai dengan penelitian yang dilakukan Haq (2016) yang melakukan penelitian di perusahaan Hutan Tanaman Industri (HTI) yang menyatakan bahwa perusahaan melakukan implementasi CSR hanya dalam bentuk charity atau bantuan yang bersifat langsung, sehingga program berkelanjutan yang ditujukan untuk memberdayakan masyarakat belum dirasakan oleh masyarakat. Indikator 7 dan 8 berada pada kuadran 3, artinya kinerja implementasi aspek hasil berupa "Program bantuan/pelatihan perusahaan PTPN V membuat aturan-aturan lokal yang ada di masyarakat menjadi lebih baik", dan "Program bantuan/pelatihan perusahaan PTPN V membuat terbentuknya badan khusus yang mengurus program yang diberikan perusahaan" menjadi prioritas rendah dalam implementasi CSR perusahaan. Indikator 7 dan 8 kurang diperhatikan oleh perusahaan karena kedua indikator ini dirasa tidak terlalu berpengaruh kepada masyarakat, tetapi ternyata telah berakibat pada ketidakpuasan masyarakat pada kedua indikator tersebut. 


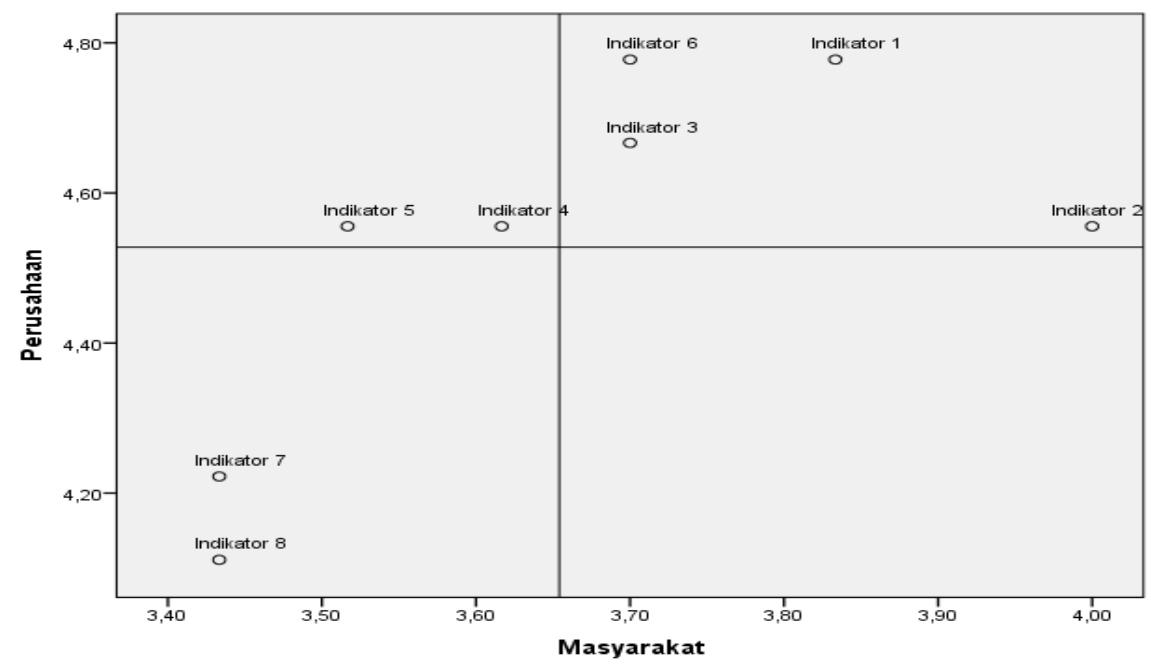

Gambar 6 Diagram IPA aspek hasil/outcome

\section{SIMPULAN}

Kinerja implementasi kebijakan CSR yang telah dilaksanakan PT Perkebunan Nusantara V tergolong sangat baik dari aspek isi kebijakan dan dukungan, namun perlu perbaikan pada aspek transparansi, program CSR dan hasil. Transparansi dan keterbukaan informasi yang lebih luas menjadi poin penting untuk keterjangkauan terhadap sasaran pemberian CSR yang lebih baik untuk kedepannya.

\section{DAFTAR PUSTAKA}

[BPS] Badan Pusat Statistik Indonesia. 2017. Statistik Kelapa Sawit Indonesia 2017. Jakarta(ID): Badan Pusat Statistik.

[IRIN] Integrated Regional Information Networks. 2010. Indonesia: Demand for Palm Oil Fuels Landgrabbing [Internet]. [diunduh 2020 Sep 16]. Tersedia pada: http://www.irinnews.org/Report/89747/INDONESIA-Demand-for-palm-oil-fuels-land-grabbing on 13/06/2012.

[Kementan] Kementerian Pertanian. 2019. Luas Areal Kelapa Sawit Menurut Provinsi di Indonesia 2015-2019 [Internet]. Jakarta (ID): Direktorat Jenderal Perkebunan Kementerian Pertanian RI. [diunduh 2020 Jul 24]. Tersedia pada: https://www.pertanian.go.id/home/?show=page\&act=view\&id=61.

Achda BT. 2006. The sociological context of corporate social responsibility development and implementation in Indonesia. Corp Soc Responsib Environ Manag. 13: 300-305.

Apriani F, Muhammad Z. 2018. Corporate social responsibility of oil palm companies in East Kutai Regency, East Kalimantan Province, Indonesia. Management. 8(1): 11-17. doi: 10.5923/j.mm.20180801.03.

Arifandy IM, Haryadi, Adiwibowo S. 2018. Analisis pengaruh adopsi ISPO terhadap perbaikan kinerja pengelolaan lingkungan dan perubahan sosial ekonomi masyarakat. Jurnal Pengelolaan Sumberdaya Alam dan Lingkungan. 8(2): 199-206. doi: 10.29244/jps1.8.2.199-206.

Budiaji W. 2013. Skala pengukuran dan jumlah respon skala likert. Jurnal Ilmu Pertanian dan Perikanan. 2(2): 127-133.

Carrafio J, Rocco J. 2007. Ten common misunderstandings, misconceptions, persistent myths and urban legends about likert scales and likert response formats and their antidotes. Journal of Social Sciences. 3(3): 106-116.

Dayne S. 2008. Oil Palm Landscapes: Indonesia's Game of Palms [Internet]. Bogor (ID): CIFOR. [diunduh 2020 Apr 11]. Tersedia pada: https://forestsnews.cifor.org/54814/oil-palm landscapes-indonesiasgame-palms?fnl=en. 
Dewani AP, Boer R, Jannah N. 2014. Analisis jejak karbon agribisnis sawit untuk menyusur arahan strategi dan program Corporate Social Responsibility (CSR). Jurnal Pengelolaan Sumberdaya Alam dan Lingkungan. 4(1): 96-104.

Haq AN. 2016. Rencana kelola sosial pembinaan masyarakat desa hutan (PMDH) di PT. Mitra Kembang Selaras Kabupaten Indragiri Hulu Provinsi Riau [skripsi]. Bogor (ID): Institut Pertanian Bogor.

Kartini D. 2013. Corporate Social Responsibility Transformasi: Konsep Sustainability Management dan Implementasi di Indonesia. Bandung (ID): Refika Aditama.

Nurfatriani F, Ramawati, Sari GK, Komarudin H. 2018. Optimalisasi dana sawit dan pengaturan instrument fiskal penggunaan lahan hutan untuk perkebunan dalam upaya mengurangi deforestasi [Internet]. [diunduh 2020 Apr 11]. Bogor (ID): CIFOR. Tersedia pada: http://www.cifor.org/publications/pdf_ files/WPapers/WP238Nurfatriani.pdf.

Pasaribu SI, Vanclay F, Zhao Y. 2020. Challanges to implementing socially-sustainable community development in oil palm and forestry operations in Indonesia. Land. 9(61): 1-19. doi: 10.3390/land9030061.

Pemerintah Indonesia. 2007. Undang-Undang No. 40 Tahun 2007 tentang Perseroan Terbatas. Lembar Negara RI Tahun 2007, No. 106. Jakarta (ID): Sekretariat Negara.

Pemerintah Indonesia. 2012. Peraturan Pemerintah No. 47 Tahun 2012 tentang Tanggung Jawab Sosial dan Lingkungan Perseroan Terbatas. Lembar Negara RI Tahun 2012, No. 89. Jakarta (ID): Sekretariat Negara.

Rist L, Feintrenie L, Levang P. 2010. The livelihoods impacts of oil palm: Smallholders in Indonesia. Biodivers Conserv. 19: 1009-1024.

Sugino T, Mayrowani H, Kobayasi H. 2015. Determination for CSR in developing countries: the case of Indonesian palm oil companies. Jpn J Rural Econ. 17: 18-34. doi: doi.org/10.18480/jjre.17.18.

Xue H, Fang C. 2018. How to optimize tourism destination supply: A case in Shanghai from perspective of supplier and demand side perception. IOP Conf Series: Earth and Environmental Science. 113: 1-5. doi: 10.1088/1755-1315/113/1/012227. 